\title{
$\begin{array}{lllllllll}\text { I } & \mathrm{N} & \mathrm{S} & \mathrm{T} & \mathrm{I} & \mathrm{T} & \mathrm{U} & \mathrm{T} & \mathrm{E}\end{array}$
}

\section{Increased Reliance on Wives as Breadwinners during the First Year of the Recession}

KRISTIN SMITH

$\mathrm{F}$ or the first time in history, women are poised to outnumber men in the workforce. ${ }^{1}$ Women's employment has been on the rise, but the massive job loss experienced by men during this recession has pushed the proportion of women in the workforce just shy of parity with men, at 49.8 percent. $^{2}$

This recession has affected men's employment more than women's. Since the start of the recession in December 2007, the U.S. economy has shed 7.0 million jobs, 72 percent of them held by men. ${ }^{3}$ In November 2009, overall unemployment was high at 10.0 percent, with men's unemployment at 10.5 percent. Women's unemployment rate was 7.9 percent. Job loss has been particularly high among African American men, lower-educated men, and workers in male-dominated industries, such as construction and manufacturing. In contrast, the economy added jobs in some female-dominated industries, such as education and health services.

This brief investigates the increased role employed wives are playing in family economic stability during the first year of the economic recession from 2007 to 2008.

\section{Increased Reliance on Employed Wives' Earnings}

One consequence of the recession for many families is a greater reliance on wives' earnings. As husbands lose their jobs, family earnings plummet, and the role of wives' earnings often becomes critical to keeping families afloat. ${ }^{4}$

In 2008, employed wives contributed 45 percent of total family earnings, a statistically significant rise from 44 percent in 2007-and the largest single-year increase during the past ten years (see Figure 1). ${ }^{5}$ Even the economic contribution made by employed wives with children under 18 increased.

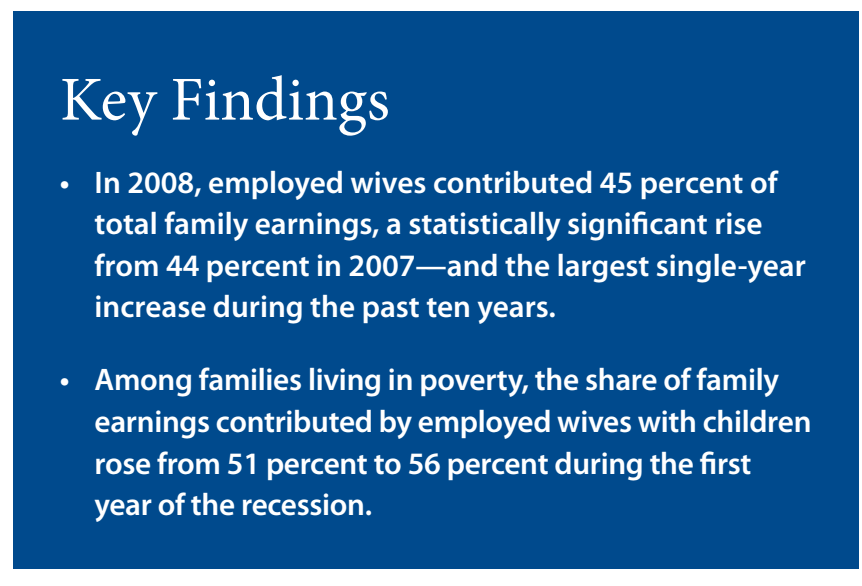

FiguRE 1. EMPLOYED WIVES' PERCENT CONTRIBUTION TO TOTAL FAMILY EARNINGS, 1999-2008

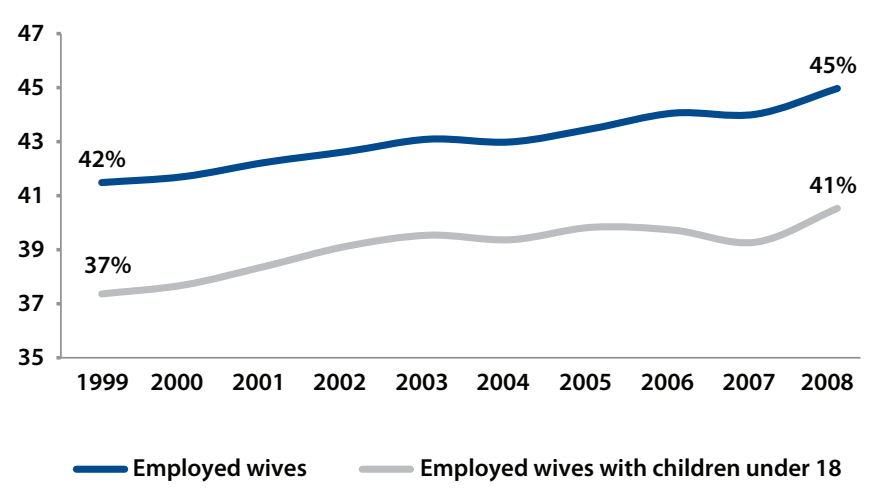

Source: 2000-2009 Current Population Survey, Annual Social and Economic Supplements. 


\section{Employed Wives Living in Poverty Contribute the Majority of Family Earnings}

Employed wives' wages account for the majority of family earnings in low-income families. Overall, the contribution of employed wives with children living in poverty rose during the first year of the recession from 51 percent to 56 percent of family income (see Figure 2). Families with more economic resources rely less on employed wives' earnings (see Table 1).

TABle 1. EMPlOYED WIVES' PERCENT CONTRIBUTION TO FAMILY EARNINGS, 2007-2008

\section{TOTAL}

Wife's poverty status

In poverty

100 to $200 \%$ of poverty

200 to $400 \%$ of poverty

$400 \%$ of poverty or higher

$44 \%$

$45 \%$

Husband's annual earnings

Less than $\$ 20,000$

$\$ 20,000$ to $\$ 39,999$

$\$ 40,000$ to $\$ 59,999$

$\$ 60,000$ or more

Husband's race

White, non-Hispanic

Black, non-Hispanic

Other, non-Hispanic

Hispanic

$58 \%$

$49 \%$

$45 \% \quad 47 \%$

$42 \% \quad 43 \%$

$80 \% \quad 81 \%$

$45 \% \quad 45 \%$

$38 \% \quad 39 \%$

$28 \% \quad 28 \%$

$43 \% \quad 44 \%$

$51 \% \quad 53 \%$

$46 \% \quad 46 \%$

$42 \% \quad 43 \%$

Husband's education

Less than high school

High school

Some college

College graduate

Place of residence

Rural

Urban

Central city

Suburban

Region

Northeast

Midwest

South

West
Figure 2. Percent Contribution to FAMily EARNINGS AMONG EMPLOYED WIVES WITH CHILDREN UNDER 18 BY POVERTY STATUS, 2007-2008

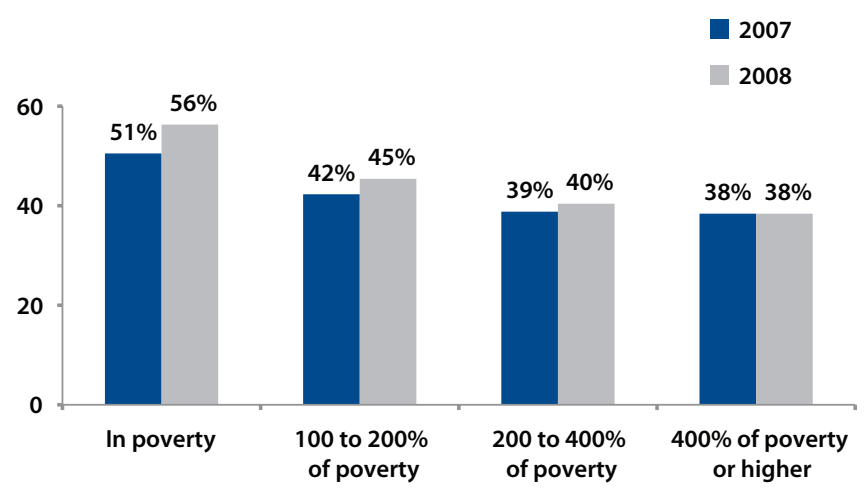

Source: 2008, 2009 Current Population Survey, Annual Social and Economic Supplement.

\section{Husband's Characteristics Influence Wives' Percent Contribution to Family Earnings}

A woman's contribution to family earnings is higher in families where husbands earn less. For example, in 2008, employed wives married to husbands earning less than $\$ 20,000$ annually contributed 81 percent of total family earnings, while those married to husbands earning $\$ 60,000$ or more annually contributed 28 percent.

Job loss has been particularly high among African American men, with their unemployment rate reaching 15.6 percent. Their struggles are added pressure on their wives. Employed wives with African American husbands contributed 53 percent of total family earnings in 2008, a higher proportion than other groups, up from 51 percent a year earlier. $^{6}$

Unemployment rates are also high among men with less education, and likewise, women shoulder more financial responsibility. When husbands had less than a high school degree, wives contributed 52 percent of total family earnings. In contrast, when husbands had a college degree, employed wives contributed 40 percent in 2008. Although unemployment is more common among those with less education, those with higher education are not immune. From 2007 to 2008 , women's share of the family earnings grew in families whose husbands had a high school degree or some college education.

Source: 2008, 2009 Current Population Survey, Annual Social and Economic Supplements. 


\section{Wives' Contribution to}

\section{Family Earnings Increase in Rural America}

The contribution to family earnings increased for both rural and urban employed wives. Among urban families, suburban wives were responsible for the increase. Wives in the central cities saw no change in their contribution to the family's coffers. Additionally, wives' proportion of family earnings increased for families living in the Midwest and the West.

\section{Broad Implications of Increased Reliance on Wives as Breadwinners}

Despite signs that the recession may be easing, rising job loss and unemployment are projected for another year, pushing more families into poverty and causing more financial strain. The importance of wives' earnings to family stability will also likely continue to grow. The bulk of job loss occurred in the beginning of 2009, after the data reported here were collected. Thus we are likely to see an even greater reliance on wives' earnings during the second year of the recession.

Wives may have been spared the bulk of job loss but only because the job market is heavily segregated by sex. Yet sex segregation in employment is a primary contributor to the gender wage gap, ${ }^{7}$ resulting in lower earnings for women and increased economic hardship for families, who increasingly depend on wives' earnings to make ends meet.

The recession is only drawing attention to a trend that has been emerging for some time now. ${ }^{8}$ Increased reliance on wives as breadwinners has broad implications. First, as more wives enter the labor force and earn wages comparable to their husbands, gender roles can change for both women and men. Mothers still do more housework than fathers, but fathers are spending more time with their children and their involvement in the family has increased. ${ }^{9}$

Second, almost half of family earnings come from wives, which draws attention to equity in the workplace. Women employed full-time year-round earn 77 percent of what corresponding men earn. ${ }^{10}$ Family economic stability depends on wives economic contribution, and families suffer when women earn less.

Third, even prior to the recession, working families were feeling work/family stress due to increased time spent working, inflexible workplaces that have not kept pace with changing families, and the lack of policy supports for working families. ${ }^{11}$ Job loss and wage cuts during a recession only add to family stress. Policies to support working families, such as paid sick leave and paid family medical leave, affordable quality child care, livable wages, and measures that increase workplace flexibility, could help reduce the work/ family conflict many men and women experience.

Finally, in the short term while America waits for jobs to return, some families need more immediate help. Expanding unemployment insurance, public assistance, and food stamps could help families make ends meet during this economic downturn. Extending tax credits to very low earners, such as the Earned Income Tax Credit, the Child Tax Credit, and the Making Work Pay Tax Credit, would also add to the family coffers. Short-term aid may be necessary to help families get by and be an important preventive measure for preserving child and family well-being.

\section{Data Used}

This brief uses data from the U.S. Census Bureau's Current Population Survey (CPS) March Supplements from 2000 to 2004 and Annual Social and Economic Supplements (ASEC) from 2005 to 2009. "Wives' contribution to total family earnings" is the ratio of wives' annual earnings to the sum of wives' and husbands' annual earnings. Comparisons presented in the text are statistically significant at the 0.05 level.

\section{EN D N O T E S}

1. This is based on Bureau of Labor Statistics, Current Establishment Survey data. The data include a monthly count of the number of nonfarm payroll jobs held, excluding self-employment, unpaid family employment, agricultural work, and private household work.

2. The possibility of women surpassing men in the workforce has garnered media attention. See Catherine Rampell, "As Layoffs Surge, Women May Pass Men in Job Force," New York Times, February 6, 2009, and Dennis Cauchon, "Women Gain as Men Lose Jobs," USA Today, September 3, 2009.

3. Bureau of Labor Statistics, "The Employment Situation, November 2009.” News Release, December 4, 2009. For more details, see http://www.bls.gov/news.release/pdf/empsit.pdf.

4. The percentage of families living in poverty rose in 2008 to 10.3 percent, and median family income declined by 3.6 percent to $\$ 50,303$. See Carmen Walt, Bernadette Proctor, and Jessica Smith, "Income, Poverty, and Health Insurance Coverage in the United States: 2008” (Washington, DC: U.S. Census Bureau, 2009).

5. In 2008,28 percent of wives age 18 to 64 were out of the labor force. When these nonearning wives are included, wives contribute 26 percent of family earnings. 
6. Similar results were found when wives' contribution to family earnings was calculated by wives' race and ethnicity.

7. Heather Boushey, “The New Breadwinners," in The Shriver Report: A Woman's Nation Changes Everything, ed. Heather Boushey and Ann O'Leary (Washington, DC: Center for American Progress, 2009).

8. Kristin Smith, Working Hard for the Money: Trends in Women's Employment 1970-2007, A Carsey Institute Report on Rural America (Durham, NH: Carsey Institute, University of New Hampshire, 2008).

9. Suzanne Bianchi, John Robinson, and Melissa Milkie, Changing Rhythms of American Family Life (New York: Russell Sage Foundation, 2006).

10. Walt, Proctor and Smith, "Income, Poverty and Health Insurance Coverage in the United States: 2008."

11. See Phyllis Moen, It's About Time: Couples and Careers (Ithaca, NY: Cornell University Press, 2003); Jerry Jacobs and Kathleen Gerson, The Time Divide (Cambridge, MA: Harvard University Press, 2004); Janet Gornick and Marcia Meyers, Families that Work: Policies for Reconciling Parenthood and Employment (New York: Russel Sage Foundation, 2003); and Ellen Galinsky, Kerstin Aumann, and James T. Bond, "NCSW 2008: Times Are Changing: Gender and Generation at Work and Home," in National Study of the Changing Workforce (New York: Families and Work Institute, 2009).

\section{A C K N O W L E D G M E N T S}

The author thanks Marybeth Mattingly, Mil Duncan, and Curt Grimm at the Carsey Institute and Barbara Ray at Hired Pen for their thoughtful comments and suggestions; Michelle Stransky for research assistance; and Terri Rippett for publications support.

\section{A B OUT THE A T THOR}

Kristin Smith is a family demographer at the Carsey Institute and a research assistant professor of sociology at the University of New Hampshire (kristin.smith@unh.edu).

\section{ANIVERSITY}

Building knowledge for families and communities

The Carsey Institute conducts policy research on vulnerable children, youth, and families and on sustainable community development. We give policy makers and practitioners timely, independent resources to effect change in their communities.

This work was supported by the Annie E. Casey Foundation's initiative to strengthen rural families, the W. K. Kellogg Foundation, and an anonymous donor.

Huddleston Hall

73 Main Street

Durham, NH 03824

(603) $862-2821$

www.carseyinstitute.unh.edu 